Вікторія ТАРАСЕНКО

асистент,

Донецький національний університет імені Василя Стуса

\title{
ПРОБЛЕМА АДАПТАЦІЇ «ПОВІСТІ ПРО САНАТОРІЙНУ ЗОНУ» М. ХВИЛЬОВОГО ЗАСОБАМИ КІНО
}

У статті проаналізовані особливості перекодування «Повісті про санаторійну зону» М. Хвильового засобами кіно. Визначена специфіка адаптації літературного твору як особливого різновиду міжмовного посередництва, встановлений зв'язок між чинниками, що іiї зумовлюють. Виявлено й описано окремі аспекти трансформації художнього змісту літературного твору, яка характеризує його втілення в форматі кіномистецтва. Здійснено порівняльний аналіз часопросторової організації першотвору та його втілення на екрані, структурних та сюжетних особливостей творів тощо.

Ключові слова: адаптачія, екранізачія, кінотранскрипџія, переклад.

Причиною зміни традиційної системи різних видів мистецтв стала поява кіно та телебачення. Проблема їх виникнення, існування та зв’язку 3 іншими видами мистецтва, зокрема з літературою, на сьогодні є недостатньо дослідженою. Виникнення кінематографу змінило світоглядні парадигми людства, позначилося на сприйнятті літературних творів, за мотивами яких були зняті фільми. Література i кіно мають багато спільного, тому їх зіставлення є цілком закономірним та актуальним на сьогодні. Екранізація будь-якого літературного твору є візуальною інтерпретацією першоджерела, тому доцільно застосовувати інтермедіальний підхід, який передбачає зіставлення сюжету, поетики, структури, стилю, мови, символіки та образної системи обох творів.

Проблема адаптації літературного твору засобами кіно завжди привертала увагу як літературознавців, так і кінознавців. Різні аспекти цього питання висвітлені в дослідженнях Людмили Волкової, Є. Габриловича, В. Дьоміна, С. Лазарука, І. Маневича, Людмили Савенкової, Л. Фрадкіна, М. Ямпольського та ін. На Заході в середині 60-х років ХХ століття активно розвивався семіотичний підхід до кіномистецтва, який наприкінці XX століття посів провідне місце в кіноестетиці. Його перевага полягає в тому, що він дозволяє здійснювати порівняльний аналіз кіномови i мови 
літератури. У 10-30-х роках XX ст. активно обговорювалася проблема мови кіно С. Ейзенштейном, Б. Ейхенбаумом, Ю.Тиняновим, В. Шкловським. Особлива увага до цієї проблеми була прикута з появою звукового кіно (Б. Балаш, В. Пудовкін, Р.Якобсон). У 60-70-і роки дослідники - У. Еко Ю. Лотман, К. Метц - активно обговорювали питання, що стосувалися нового напрямку кінознавства: семіотики кіно. Вони аналізували проблему сутності мови, типи знаків, зіставляли ці знаки з вербальними.

Загалом екранізація вважається перекладом із мови літератури на мову кіно. Проте аналіз цього феномену дозволяє припускати, що адаптація літературних творів засобами кіно - це новий вид художньої творчості, який зародився ще у XX столітті та потребує детального дослідження. Отож, актуальність дослідження визначається необхідністю простежити специфіку перекодування повісті М. Хвильового на різних рівнях (насамперед стильовому) засобами кінематографії, що дає можливість розширити обрії осмислення авторського доробку.

Термінологія, яка стосується кіномистецтва та його зв'язку 3 літературою, збагачується: виникають нові терміни (зокрема переклад, адаптація, кінотранскрипція) і поняття. Так, переклад давно вже трактується літературознавцями як складник літературної компаративістики, адже він, на думку М. Ільницького й В. Будного, є важливим об’єктом порівняльного дослідження, одним із видів міжлітературної та міжкультурної взаємодії. Такий підхід до перекладу можна вважати плідним і перспективним, адже дослідження специфіки й особливостей адаптації літературного твору під час перекладу збагачує уявлення про рецепцію твору в культурі перекладу. Явище адаптації при перекладі - особливий різновид міжмовного посередництва. Дослідження різних аспектів адаптації здійснювали Ю. Найда, В. Коміссаров, Я.Рецкер, А. Паршин, Ж.-П. Вене, Ж. Дарбельне, Ж. Бастін та інші.

В англомовній літературі використовується поняття adaptation (лат. adaptatio, adapto - пристосовую), у польській мові - adaptacja. У 
літературознавчому словнику Ю. Коваліва подається таке визначення: «Адаптація - це пристосування літературного твору до його розповсюдження в іншому вигляді, ніж оригінальний; результат цього - пристосування» $[1$, с. 9]. Традиційно вважається, що перше визначення поняттю «адаптація» дали Ж.-П.Вене й Ж. Дарбельне. Вважаючи іiі перекладацьким прийомом, вони стверджували, що адаптацією можна назвати процедуру, яка застосовується, щоб досягнути еквівалентності ситуацій скрізь, де є культурні розбіжності.

На відміну від попередників, Ж. Бастін не приписав цьому прийому жодних специфічних характеристик. «Адаптація, - вважає вчений, - набір перекладацьких дій, унаслідок яких з'являється текст, що не приймається в якості перекладу, однак визнається таким, що репрезентує першоджерело й має приблизно такий же обсяг» [6, с. 5]. Він виділяє кілька адаптивних стратегій, які слід ураховувати, переносячи текст з одного виміру в інший: значення й очікування цільового реципієнта (автор адаптації має оцінити, в якій мірі зміст першоджерела подає нову чи відому інформацію для аудиторії); пошук пари для стилю дискурсу первинного тексту (автор має подбати про узгодження форм адаптації); значення й мета первинних і цільових текстів.

Враховуючи подані дослідником стратегії, можна відзначити, що режисер, коли перекодовує літературний твір, повинен зіставити першоджерело з його потенційною кіноверсією, чітко продумати засоби перекодування твору, стиль, жанрову специфіку, мотив й ідею літературного твору.

Інтермедіальний характер гуманітарних досліджень у сфері адаптації чітко виражений у працях, присвячених адаптації літературних творів для кіно (Б. Макфарлейн «Від роману до фільму», Т. Лейнч «Дванадцять помилок сучасної теорії адаптації», Р. Стем «Теорія та практика адаптації»). Так, Т. Лейнч пропонує розглядати адаптацію разом із дослідженнями, присвяченими зв'язку літератури i кіно, а також у межах текстуальних досліджень. Про текстуальну, інтермедіальну й транстекстуальну природу адаптації пише й Р. Стем. На його думку, адаптацію більш продуктивно 
розглядати не як комунікативну, а як герменевтичну стратегію, як інтерпретацію попередніх матеріалів, що пропонується трансформаційними операціями у відповідності до різних чинників, специфічних для такого медіуму, як кіно. Дж. Нермор вважає, що інтермедіальний характер розповсюджується на всі види мистецтва.

Враховуючи погляди дослідників на проблему адаптації літературного твору в кінопросторі, слід відзначити, що у процесі адаптації першотекст змінює не лише медіум, у якому він уперше з'являється, а й дисципліну, в якій він досліджується. Інтермедіальний та міждисциплінарний підходи до дослідження адаптації простежуються у працях Лінди Хатчеон («Теорія адаптації»), яка розглядає адаптацію як розгорнуте повторне звернення до конкретного твору мистецтва. Дослідниця розширює сферу застосування адаптації: «Моє більш обмежене подвійне визначення адаптації як процесу і продукту ближче до загальноприйнятого вживання цього слова i досить широке, що дозволяє мені аналізувати не тільки фільми і театральні постановки, але й музичні аранжування, кавер-версії пісень, повторне відтворення попередніх творів візуального мистецтва, комікси з історичних творів, вірші, покладені на музику, римейки фільмів, відеоігри та інтерактивні види мистецтв» [5, с. 9]. Також, на думку дослідниці, адаптація - це повтор без дублювання, форма інтертекстуальності: «Після адаптації форма змінюється, а зміст зберігається» [5, с. 13].

Незважаючи на те, що Лінда Хатчеон не наводить конкретних прикладів зв’язку між інтермедіальною та перекладацькою адаптацією, вона все ж таки вказує на спорідненість обох процедур. «У багатьох випадках, зауважує дослідниця, - оскільки адаптація призначена для іншого медіуму, вона $\epsilon$ ремедиацією, а саме перекладом у вигляді інтерсеміотичних транспозицій 3 однієї знакової системи (наприклад, слова) на іншу (наприклад, зображення). Це переклад, але в дуже вузькому значенні: у вигляді трансмутацій або транскодування, тобто у вигляді запису в новому наборі конвенцій, а також знаків» [5, с. 16]. 
Синонімічним до поняття «адаптацุiя» можна вважати «кінотранскрипиію» (грец. рухаю і лат. transcriptio - переписування). Цей термін з'явився порівняно недавно i має кілька визначень. Так, М. Гловінський вважає, що кінотранскрипція - це перенесення певного літературного твору в знакові системи інших видів мистецтва: пісні, ілюстрації, спектаклю, фільму. Юлія Пушак кінотранскрипцією називає продукт взаємодії літератури і кіно на різних рівнях, процес і наслідок перенесення літературного твору на екран.

Головним критерієм оцінки кінотранскрипції вважається відповідність першотвору (повна чи часткова), у межах якої можна виділити вірність букві чи духу оригіналу. Перший тип означає пряму, близьку до першотвору, екранізацію, а другий - відповідність магматичній (іманентній) ідеї літературного твору. Як правило, повністю відповідаючи «букві» при створенні кінофільму, режисер втрачає свою самостійність, своє обличчя i власне «еgo», бо наслідує манеру письменника, стиль та ідею вже написаного і відомого всім твору. Наслідування ж літературного «духу» дає можливість режисеру самостійно перекодувати літературний твір, увести в кінофільм нові барви і стиль. Саме такі кінотвори вважаються оригінальними.

Юлія Ідліс зауважує, що в останні десятиліття дискусія, яка стосується феномену екранізації літературних творів, відбувається у двох напрямах. «В межах одного з них, - зазначає дослідниця, - літературознавці говорять про медійні (або «мовні») відмінності між літературою і кіно: саме вони певною мірою відповідальні за текст екранізації, адже роль автора виявляється незначною; екранізація, таким чином, виступає як один з варіантів тексту, який пише сам себе, «складаючись» 3 діалогу двох медіа. В межах другого підходу більше уваги надається читацько-глядацькому сприйняттю екранізації, яке також формує авторську інтенцію сценариста-адаптатора» [2, с. 11]. У будь-якому випадку, екранне втілення літературного твору вимагає інтерсеміотичного залучення кодів 3 інших знакових систем, тобто використання кіномови, виражально-зображальні засоби якої (монтаж, 
побудова кадру та його предметне наповнення, акторська гра, музичний супровід тощо) відрізняються від художніх засобів мистецтва слова. Неможливість абсолютно точно передати художній зміст літературного твору за допомогою мови іншого виду мистецтва спричинює його смислове переакцентування, внесення нових художніх значень у його екранну версію, що можна побачити на прикладі екранізації «Повісті про санаторійну зону» фільму «Танго смерті».

Фільм сприймається через призму подолання певних комплексів так званої доби «дорослішання». Це вивляється в тому, що режисер звертається до «табуйованої» тематики. Так, у фільмі постають відверті еротичні картини, повною мірою виявляються ті проблеми, які М. Хвильовий у свій час намагався завуалювати. Фільм має ознаки кількох кінематографічних жанрів: історичної драми, мелодрами. Кінематографічна інтерпретація «Повісті про санаторійну зону» сфокусована на пострадянських рефлексіях, зумовлена прагненням до відновлення історичної справедливості.

Одним із найсуттєвіших відхилень від сюжету першотвору в фільмі можна вважати сцени із минулого анарха. Складається враження, що ці кадри рівномірно розкидані по фільму і з'являються в непередбачуваний момент, щоб пояснити поведінку героя. Наприклад, після зустрічі анарха з Майєю, коли чоловік чи не вперше відмовив їй у близьких стосунках, подається сцена, під час якої анарх вбиває свою жінку через зраду. Таким чином, режисер підкреслює недовірливе ставлення героя до жінок. Після розмови анарха 3 Карно 3'являються кадри 3 часів революції: зображено, як герой вбиває багатіїв та представників влади. Із кадрів стає зрозуміло, що практика анархістів, втіленням яких є Савонарола, вражала жахливими особливостями, адже анархісти вдавалися до масового терору (залякування визискувачів i влади), економічного терору, що мав допомогти так званому робітничому руху. Пропаганда анархістів мала підштовхнути маси до рішучих дій, до масової кривавої розправи, фізичного знищення десятків тисяч гнобителів. Через свою ворожість до влади й культ насилля вони вважали, що на шляху 
до масового терору об’єкт терору може вибирати окрема революційна анархічна особистість, якою й постає у фільмі Савонарола. У повісті такі деталі відсутні: анархізм героя підтверджують лише його прізвисько та натяки Майї. Це спричинено тим, що письменник намагався приховати справжні мотиви твору.

Показовою в кінострічці є сцена приходу до анарха чоловіка, який є нібито співробітником тієї організації, в якій працює герой. Під прикриттям обговорення контракту з німцями чоловік попереджає Савонаролу про те, що багатьох його однодумців викрили: «Я не хотів вас засмучувати, Ельфільмана теж...уночі 3 ліжка. Брат належав до бунту. Петерса (iз латиських стрільців) теж узяли. Що тут сказати, їм видніше» [3]. Режисер намагався повною мірою відтворити все те, про що мовчав або майстерно приховував письменник.

У повісті відсутня сцена самовбивства анарха, письменник обмежився лише алюзією на смерть головного героя: «На далеких бойнях ревів віл, і рев був тягучий і тривожний. Але анарх його не чув. I вже не бачив він другого берега, де сидів Карно й саркастично всміхався. Упала одна крапля, друга i раптом замжичило. Невеселий осінній дощик біг, спотикаючись, до санаторійної зони. Зашуміли ринви. I печальну елегію осінньої чвирі замкнула похоронна процесія» [4, с. 160]. Режисер же вирішив відобразити цю картину: анарх, зайшовши до своєї кімнати, побачив на ліжку пістолет, прикритий Майїною хусткою, після чого пролунав постріл. Таким чином, О. Муратов у черговий раз підкреслив, що і в духовній, і в фізичній смерті так званих «зайвих людей» винні представники тогочасної влади. У своєму фільмі він акцентував приховувані до того часу постреволюційні проблеми.

Слід звернути увагу на редукцію окремих епізодів повісті. Наприклад, у кіноінтерпретації відсутні розмови на антирелігійні теми, сцени написання листа анарха до своєї сестри, приходу Савонароли в будинок Катрі тощо. Митець навмисно опускає ці фрагменти, щоб не перенавантажувати сюжет кінокартини. На перший план він висуває мотив переслідування інакодумця 
системою. Так, у центрі твору, як і в повісті, постає Анарх, до якого було приставлено жінку-агента НКВС Майю, щоб та викрила всі його секрети й спровокувала розвиток істерії героя, який, зрештою, мав привести його до самогубства. I якщо в повісті цей герой ніби змішується з іншими хворими, що допомагає письменникові приховати антиполітичні мотиви твору, то в екранізації режисер навмисне приковує всю увагу реципієнта саме до нього, свідомо стираючи роль інших персонажів: Хлоні, Унікуму, Катрі. Савонарола опиняється віч-на-віч із системою, втіленням якої $є$ Карно та Майя, яка, зрештою, перемагає.

Відрізняється й фінальна частина обох творів. Повість закінчується смертю анарха (про долю інших героїв уже нічого не сказано), а в фільмі режисер вирішив додати ще один епізод із Майєю, яка після самогубства Савонароли отримує ще одне завдання: знищити меншовика, грузинського князя, красеня. Режисер, таким чином, показує, що доля анарха - це доля всього тогочасного суспільства, яке не змирилося 3 постреволюційною дійсністю, і те покоління, нехай не фізично, проте духовно, було знищене.

Режисер, знімаючи фільм, максимально відтворив колорит тієї епохи. Так, в окремих сценах можна побачити популярну на той час газету «Вісті», пропагандистський плакат із надписом «Знищимо опозицію!», автомобілі, деталі інтер'єру, одяг тощо. Аура часу, відтворена засобами кіно, занурює глядача у стихію 1920-х, побачену на тлі розсіяного контражуру. Живі, темпераментні персонажі фільму немовби пронизані потужним світлом. Такий спосіб знімання творить тривожну атмосферу приреченості.

Не слід применшувати значення характерів, зіткнення особистостей, яким випало пережити пристрасті, нестерпне розчарування в ідеалах. Відтворення історичного часу - одне із найскладніших завдань кіно, i постановник для його вирішення обирає різні шляхи і способи. Одних вабить умовність, інші прагнуть автентичності і життєвої достовірності, а когось матеріальне втілення історичного часу загалом не цікавить. Крім того, 
постановник у відтворенні історичної доби керується не лише естетичними міркуваннями, а й фінансовими можливостями.

Відмінним між повістю та фільмом є зображення природи. Так, якщо в першоджерелі наскрізними є осінні пейзажі («передосіннє сонце стояло в згустках опару» [4, с. 106]), подекуди навіть забарвлені сірістю та похмурістю («насувалась темна, мало не таємна гроза» [4, с. 115], «поринав у багрянцях захід, і тоді чекали шалених вітрів» [4, с. 131], «невеселий осінній дощик біг, спотикаючись, до санаторійної зони» [4, с. 166]), то в екранізації природа нагадує більше літню пору року. В фільмі герої одягнені політньому, навкруги - одна зелень, квіти, сонячна погода, яка, до речі, не змінюється разом із перебігом подій, як це можна спостерігати в повісті.

Якщо говорити про часовий проміжок повісті й кіноверсії, то в повісті він чіткіший, ніж у фільмі. Так, у творі М. Хвильового всі події відбуваються восени: від ранньої до пізньої. В екранізації ж часовий проміжок можна визначити умовно, адже тут немає жодних маркерів, які б натякали на зміну часу, окрім дня й ночі. Проте в фільмі теперішнє переплітається з минулим, тому створюється ефект регресу (рух назад, повернення до вже пережитого).

Відмінним у повісті і їі екранізації є зображення санаторійної зони. У художньому творі вона відокремлена від усього світу (у реципієнтів вона нерідко асоціюється з територією концтабору), охороняється стрільцями, за їі межі без дозволу вийти ніхто не може. Письменник, зображуючи зону, намагався підкреслити факт ізольованості й цілісності місця, де відбуваються всі дії, його завершеність та самодостатність. Її можна назвати саркастичною алегорією механізованого суспільства, місцем, де зібрані міщани, філософи, інтелігенція, пролетарі, пристосуванці, революціонери. Її можна порівняти 3 в’язницею, адже тут є всемогутні начальники-ординатори, коменданти, режим, який детально описує Унікум: «О восьмій годині дзвоник, потім сніданок, другий сніданок, обід, чай, вечеря. Між ними лежанки, з яких одна — мертва. В години лежанок завше непорозуміння з сестрами. Як бачите, без цього не можна: один хворий недисциплінований, другий - просто випадково 
не дотримується режиму. Наприклад, на мертвій лежанці замість того, щоб лежати колодою: дехто зривається й кудись уходить... А то з куріями нелади, бо ж режим не дозволяє вживати тютюну» [4, с. 75].

У повісті територія зони має чітко окреслену межу, якою виступає річка. Вона час від часу з'являється в повісті від самого початку аж до самогубства анарха. У творі вона символізує, по-перше, сакральну топографію, межу, яка відділяє зону від усього світу, по-друге, за давніми віруваннями річка відокремлює світ живих від світу мертвих, вона є входом до царства мертвих (тут можна згадати Хлоню, який потонув). Річка зображується і в фільмі, проте тут вона постає більше прихистком, а не межею, адже саме біля води герої відпочивають, обдумують сенс життя, саме тут відбуваються відверті діалоги між анархом та Катрею, Майєю, Хлонею. У фільмі річка розлога, з блакитною чистою водою, в якій відблискує сонячне проміння.

У повісті санаторійна зона має кілька локусів: саме приміщення санаторію (палата), яке письменник детально не змалював, двір, ліс, яблуневий сад і командна висота, розташована над річкою. Остання в фільмі i в повісті символізує пізнання істини, адже саме тут Майя зізнається, що вона - таємна чекістка, саме тут анарх дізнається про смерть Хлоні. Санаторій i територію, що до нього прилягає, можна умовно поділити на три рівні (за Ю. Безхутрим): до першого рівня належить гора (командна висота), до другого приміщення санаторію (у повісті, на відміну від екранізації, воно детально не описане), до третього - берег річки, луки (саме тут Хлоня прощається 3 життям).

У фільмі «Танго смерті» санаторій зовні нагадує справжнє місце відпочинку: гарна будівля, оформлена в бароковому стилі, велика територія, яка виводить і в ліс, і до річки, парасольки й лежаки для відпочинку, біла статуя як елемент декору, великий ганок, де обідають герої, тощо. На початку фільму на території санаторійної зони зображено невелику купку людей, які займаються своїми справами: хто читає, хто малює, хто просто засмагає, 
тобто жодних асоціацій із замкненим простором не виникає. Детально зображений інтер’єр кімнати анарха: в ній є всі необхідні меблі, стоять квіти в горщиках, годинник, велике вікно, що виходить у двір. Те, що санаторійна зона не асоціюється в фільмі з в’язницею, підтверджують й інші факти: тут люди весь час розважаються (грають у карти, на музичних інструментах, ходять на прогулянки, купаються в річці, декламують твори відомих письменників, зокрема ординатор увечері читає пацієнтам уривок із твору М. Гоголя «Вечори на хуторі біля Диканьки», можуть навіть випити горілки ввечері). Отож, у фільмі ця територія зображена в позитивному ключі. Режисер удався до такого прийому для того, щоб створити інтригу, досягти видимості того, що картина буде про курортний роман, а потім поступово акцентувати проблематику.

Цікавим $\epsilon$ початок i кінець творів. Якщо повість починається й закінчується словами, взятими з щоденника хворої, то в екранізації замість цього режисер використовує танець - танго. Саме таке зовнішнє обрамлення й відсилає реципієнта до заголовка. Літературний твір і його екранізація називаються по-різному, адже режисер намагався акцентувати те, що М. Хвильовий подавав у завуальованій формі.

Перше знайомство із твором відбувається завдяки заголовку, тому М. Хвильовий розумів, що саме назва твору є ключем до його розуміння, вона має сконцентровувати сенс мистецького твору, відбивати авторський задум, привертати увагу до домінантних складників твору. Письменник назвав твір «Повістю про санаторійну зону» і тим самим заклав у заголовок протиріччя: слово «санаторійна» має позитивне значення, асоціюється 3 відпочинком, а «зона» має негативну конотацію, адже це місце ув’язнення, смерті. Між заголовком і текстом повісті теж виникають своєрідні зв'язки: в цій «санаторійній зоні» назавжди виліковують від останніх залишків ілюзій, мрій, надії, залишаючи людину в’язнем власного розпачу, внутрішньої порожнечі й безвиході. У повісті санаторій зображений як місце, де люди, які розчарувалися в житті, втратили свої ідеї та переконання, повинні 
виліковуватися, проте відпочинок сприяє лише тому, що персонажі ще більше заглиблюються у свої думки та шукають своє місце в постреволюційній дійсності. Через це їх покарання відбувається не на фізичному, а на моральному рівні.

Режисер (на відміну від «Вальдшнепів») називає фільм по-іншому «Танго смерті», прагнучи, таким чином, інтерпретувати літературний твір під іншим кутом зору й актуалізувати ті проблеми, про які намагався змовчати письменник. Режисер, як і письменник, теж поєднує в назві два протилежних за конотацією поняття: «танго» - це танець, тобто радість, позитивні емоції, пристрасть, певна сценічна гра, а у слово «смерть» апріорі закладено негативне значення, вона символізує кінець усього або переродження. Варто зазначити, що танго, яке виступає художнім обрамленням фільму, - це не звичайний танець, адже в нього митець уклав маркери, які допомагають краще зрозуміти суть твору. Насамперед мова йде про одяг танцівників: жінка одягнена в чорну сукню й такий же капелюшок (що асоціюється 3 похоронною процесією), а в убранні чоловіка показовими є дві речі: чорні рукавички (такі, як відомо, вдягають, скоюючи вбивство) та маска (скелета чи навіть примари, бо має біло-сірий відтінок). Остання відіграє важливу роль, адже має суттєве символічне навантаження, яке надає підтексту кінематографічній інтерпретації. У фільмі, як і, зрештою, в повісті, майже все герої одягнені в маски. Саме маска допомагає людині перетворитися на іншого персонажа, який може вчиняти дії, неможливі у звичайному життя, відчувати себе перетвореною не лише зовні, а й внутрішньо

Режисер, намагаючись переконливо відтворити колорит епохи та перенести задум письменника на кінотло, досить скрупульозно підійшов до підбору кінематографічних засобів, акторів, художніх деталей. Митець майстерно продумав усе до найдрібніших подробиць: починаючи від вибору місцевості, де відбуваються дії, й закінчуючи одягом та гримом персонажів, музичним супроводом тощо. Такий підхід до стрічки допоміг йому створити фільм, який не лише частково екранізує повість М. Хвильового, а й 
допомагає виявити всі жахи 1920-х років, показати різке протистояння між колишніми революціонерами, які стали зайвими, нікому не потрібними людьми, та владою.

Санаторійна зона, зображена в фільмі та повісті, - це міні-модель антисуспільства всередині системи. Тут реальність, сни, марення, видіння починають втрачати свої межі, сплітаючись в одну химерну цілісність. Санаторій - це місце, де усі, хто там знаходи ться, приречені, усе повторюється знову і знову, і від цього нікуди не дітись, і Карно нікуди не зникає, тобто метранпаж може померти лише з анархом. Таким чином, події переносяться в якусь неправдоподібну реальність, де сон, реальність та вигадка переплітаються у свідомості персонажа, втрачають причиновонаслідкові зв’язки. Це місце без перспективи, без мети, без телеології.

Отож, екранне втілення «Повісті про санаторійну зону» характеризується ускладненням структури наративу, певним переакцентуванням конфлікту, розширенням символічного підтексту, частковою зміною сюжетно-композиційної тканини твору. Режисер у цілому зберіг основу першоджерела, хоча й без певних трансформацій не обійшлося, адже перед ним стояло завдання - показати відомий твір у новому ракурсі. Органічне поєднання прийомів монтажу, мови й гри акторів, одягу та гриму, елементів інтер’єру, екстер’єру та вдало підібраних локусів, гри світла, музичного супроводу, танцю та інших художніх деталей допомогло режисерові створити насичений подіями фільм, у якому відтворено колорит зображеної епохи та дух першотвору.

\section{ЛІТЕРАТУРА}

1. Гром'як Р., Ковалів Ю. Літературознавчий словник-довідник / Роман Гром'як, Юрій Ковалів. - К.: ВЦ «Академія», 1997. - 752 с.

2. Идлис Ю. Б. Категория автора в тексте сценарной адаптации (на материале сценариев Гарольда Пинтера): автореф. дисс. на соискание ученой степени канд. фил. наук / Юлия Идлис. - Москва, 2006. - 36 с.

3. Муратов О. Танго смерті / Олександр Муратов. - Кіностудія: Національнокультурний виробничий центр Рось. - 1991.

4. Хвильовий M. Санаторійна зона: Оповідання, новели, повісті, памфлет / Худож.оформлювач І. В. Осіпов // Микола Хвильовий. - Харків: Фоліо, 2008. - 382 с. 
5. Hutcheon L. A Theory of Adaptation.London\&New York, Routledge, xviii, 2006. $232 \mathrm{p}$.

6. Vandal-Sirois H. \& Bastin G.L. Chapter 1. Adaptation and Appropriation: Is there a Limit? // Translation, Adaptation and Transformation.London\& New York, Continuum International Publishing Group, 2012. - P. 21-41.

\title{
REFERENCES
}

1. Hromiak R., Kovaliv Yu. Literaturoznavchyi slovnyk-dovidnyk [Literary Dictionary], Kyiv, VTs «Akademiya», 1997, 752 p [In Ukrainian].

2. Idlis $Y u$. B. Kategoriya avtora $\mathrm{v}$ tekste stsenarnoy adaptatsiyi (na materiale stsenariyev Harolda Pyntera): avtoref. diss. na soiskanye uchenoy stepeni kand. fil. nauk [The category of author in the text of scenery adaptation: thesis of PhD work in Philology], Moskva, 2006, $36 \mathrm{p}$ [In Russian].

3. Muratov $O$. Tanho smerti: film [The tango of death: the movie], Kyiv, Kinostudiia: Natsionalno-kulturnyi vyrobnychyi tsentr Ros, 1991 [In Ukrainian].

4. Khvylovyi M. Sanatoriina zona: Opovidannia, novely, povisti, pamphlet [Sanatorium zone: stories, short stories, novels, pamphlet], Kharkiv, Folio, 2008, 382 p [In Ukrainian].

5. Hutcheon L. A Theory of Adaptation, London\&New York, Routledge, XVIII, 2006, $232 \mathrm{p}$ [In English].

6. Vandal-Sirois H. \& Bastin G.L. Chapter 1. Adaptation and Appropriation: Is there a Limit?, Translation, Adaptation and Transformation, London\& New York, Continuum International Publishing Group, 2012, pp. 21-41 [In English].

\begin{abstract}
АННОТАЦИЯ
Виктория Тарасенко. Проблема адаптации «Повести о санаторной зоне» Н. Хвылевого средствами кино.

В статье проанализированы особенности перекодировки «Повести о санаторной зоне» Н. Хвылевого средствами кино. Определена специфика адаптации литературного произведения как особого вида межъязыкового посредничества, установлена связь между факторами, обусловливающими ее. Выявлены и описаны отдельные аспекты трансформации художественного содержания литературного произведения, которые характеризует его воплощение в формате киноискусства. Сделан сравнительный анализ пространственно-временной организации подлинника и его воплощения на экране, структурных и сюжетных особенностей произведений и тому подобное.
\end{abstract}

Ключевые слова: адаптация, экранизация, кинотранскрипџия, перевод.

\section{ABSTRACT \\ Victoria Tarasenko. The problem of the adaptation of M. Hvylovyy's «The tale of the sanatorium zone» using movie.}

The article analyzes the peculiarities of translation of M. Hvylovyy's «The tale of the sanatorium zone» using movie, which makes possible expansion the horizon of comprehension of the author's legacy. Specific features of adaptation of a literary work are represented as a special kind of interlinguistic mediation, also is established relationship between factors that cause it. It was found that in the process of adaptation of original it changes not only by the medium in which it first appears, but also by the discipline in which it is explored. It is noted that along with the term adaptation is used term of film transcription (transfer of certain literary works sign systems in other art forms, product literature and film interaction at different levels) and translation (as an important object of comparative study, one of the species of intercultural and 
interliterary cooperation). It indicates the enrichment of terminology relating to the cinema and its relationship with literature, and this, in turn, opens new perspectives for further research.

Discovered and described some aspects of the transformation of the artistic content of a literary work that describes its implementation in the form of cinema. The comparative analysis of the time and spatial organization of original and its implementation on the screen, structure and plot features of this work. The specificity of the adaptation of literary works as a special form of interlingual mediation, the relation between the factors contributing to it. Identified and described several aspects of the transformation of the artistic content of a literary work, which describes his incarnation in the format of cinema. A comparative analysis of spatio-temporal organization of the original and its incarnations on the screen, the structural and narrative features of the works.

Key words: adaptation, screening, movie transcription, translation. 